\title{
HLA Class II Histocompatibility Antigen DRB
}

National Cancer Institute

\section{Source}

National Cancer Institute. HLA Class II Histocompatibility Antigen DRB. NCI Thesaurus.

Code C29573.

HLA class II DR beta chain proteins (26-28 kD) form heterodimers with alpha (DRA)

chains, both anchored in the membrane. Expressed in antigen presenting cells ( $B$ lymphocytes, dendritic cells, macrophages), alpha/beta heterodimers present peptides derived from extracellular proteins. Hundreds of DRB alleles have been described and typing for these polymorphisms is done for transplantation. ( $\mathrm{NCl}$ ) 